\title{
Avalovara, de Osman Lins, e a realização trágica do homem e da obra de arte
}

\author{
Avalovara, by Osman Lins, \\ and the tragic realization of man and the work of art \\ Harley Farias DOLZANE* \\ Universidade Federal do Pará (UFPA) \\ Antônio Máximo FERRAZ** \\ Universidade Federal do Pará (UFPA)
}

\begin{abstract}
RESUMO: Objetiva interpretar Avalovara, de Osman Lins, em diálogo com a dinâmica trágica de velamento do real que se dirige ao homem para a realização, através da linguagem, não só do texto literário, mas também do texto de sua própria existência. No entrelaçamento de oito diferentes narrativas, revela-se a estrutura trágica do romance a partir de um palíndromo: um quadrado e uma espiral que determinam o desenvolvimento da trama na tensão Destino/Liberdade, Espaço/Tempo, Limite (quadrado) / Ilimitado (espiral), articulados na Linguagem. O trágico também surge no desempenho dos personagens, vez que estão lançados numa travessia de autoprocura que lhes solicita constantemente a (re)elaboração criativa da existência como própria possibilidade de realização humana. Portanto, é possível estabelecer correlação entre a figuração do homem e da obra literária. Ambos são ficcionais: seus sentidos configuram-se na Linguagem, num diálogo entre diversas narrativas que se entrecruzam para constituir o tecido da existência.
\end{abstract}

PALAVRAS-CHAVE: Hermenêutica. Trágico. Existência. Obra de Arte.

ABSTRACT: This study aims to interpret Avalovara by Osman Lins in dialogue with the tragic dynamic veiling of reality that addresses, through the language, the man to perform, not only the literary text, but also the text of his own existence. In the intertwinement of eight different narratives, the tragic structure of the novel is revealed from a palindrome, a square and a spiral that determine the development of the plot tension Fate/Freedom, Space/Time Limit (square) / Unlimited (spiral) articulated in the language. The tragic also arises in the performance of the characters, as they are thrown into a journey of self-seeking calling them constantly to remaking creatively the existence as the very possibility of human achievement. Therefore, it is possible to establish correlation between figuration of man and literature. Both are fictional: configure your senses in the language, a dialogue between the various narratives that intertwine to form the tissue of existence.

KEY-WORDS: Hermeneutics. Tragic. Existence. Work of Art.

E um grande mar de emoção ouvia-se dentro de mim...

Sou nada...

Sou uma ficção...

(Álvaro de Campos)

\footnotetext{
* Mestrando em Teoria Literária, Instituto de Letras e Comunicação, Programa de Pós-Graduação em Letras, Universidade Federal do Pará (UFPA). Belém - Pará. E-mail: hfdolzane @ gmail.com.

* Doutor em Teoria Literária, Professor Adjunto, Instituto de Letras e Comunicação, Programa de PósGraduação em Letras, Faculdade de Letras, Universidade Federal do Pará (UFPA). Belém - PA. E-mail: profmaximoferraz@gmail.com.
}

(C) Revista Moara ISSN 0104-0944 (Impresso), n.37, jan.-jun., Estudos Literários, 2012.

Programa de Pós-Graduação em Letras / Universidade Federal do Pará. Todos os direitos reservados. 


\section{Introdução: Avalovara: um grande pássaro feito de pequenos pássaros}

Publicado em 1973, Avalovara, de Osman Lins, é uma obra constituída do entrelaçamento de diferentes narrativas, estruturadas a partir de três elementos "claros, nítidos e nem por isso menos esquivos" (LINS, 1974, p. 73). São eles: 1 - o palíndromo SATOR AREPO TENET OPERA ROTAS, que pode ser traduzido tanto por "o lavrador mantém cuidadosamente a charrua nos sulcos" quanto por "o criador mantém cuidadosamente a obra ou o mundo na sua rota ou órbita"; 2 - um quadrado subdividido em vinte e cinco quadrados menores, cada qual comportando uma letra do referido palíndromo; 3 - uma espiral inscrita sobre o quadrado maior.

Sendo o palíndromo constituído de oito diferentes letras, cada uma originará um tema ou narrativa, de modo que a linha da espiral, sobrevoando cada quadrado menor, a intervalos regulares, é o que determina, ao longo da obra, o aparecimento, a retomada e mesmo a extensão dos fragmentos de cada narrativa.

A maioria das estórias se entrecruza no personagem $\mathrm{Abel}^{1}$, um escritor iniciante que se lança em busca do domínio da criação artística, do amor, e do autoconhecimento figurados na procura por uma cidade mítica vislumbrada ainda em sua infância, numa cisterna na Recife natal.

A procura se traduz num verdadeiro percurso rumo à plenitude existencial. Nele, Abel será conduzido por três mulheres: Cecília, Anneliese Roos e uma terceira, sem nome, identificada apenas por um símbolo gráfico: $\odot$. Ainda em Recife, Abel encontrará a primeira, Cecília, cuja condição de hermafrodita suscita a conjugação dos princípios masculino e feminino, geradores do universo. Após a morte dela, Abel parte para a Europa $^{2}$, onde conhece Anneliese Roos, uma alemã em cujo corpo várias cidades desabitadas se revelam, sendo ela mesma todas as cidades e também nenhuma. ${ }^{3}$ Em São Paulo, Abel se tornará amante de $\odot$, mulher duas vezes nascida e cujo corpo é formado por palavras. ${ }^{4}$ Com ela, Abel alcançará, enfim, o término de sua busca, que culminará na morte dos amantes e no encontro do Paraíso.

Há também a estória do escravo Loreius e de seu senhor Publius Ubonius, que viveram em de 200 a.C., na cidade de Pompéia. Ubonius prometeu liberdade a Loreius caso este fosse capaz de criar uma frase que pudesse ser lida em todos os sentidos e que

\footnotetext{
${ }^{1}$ O resgate de uma dimensão sagrada da criação literária, que se observa ao longo de toda obra de Osman Lins, permite inferir que a escolha do nome do personagem não é sem motivo. Abel revela, já a partir de seu nome, uma condição ambígua, inerente à toda criação: na Bíblia, Abel, sendo fillho do pecado, é também o homem escolhido do Criador. No prefácio da $2^{\mathrm{a}}$ edição da obra, Antonio Candido considera que Avalovara "se situa numa ambigüidade ilimitada". DALCASTAGNÉ (2000) defende um diálogo entre a construção de Abel e mitos da tradição grega, judaico-cristã e com outros personagens que figuram uma espécie de interlúdio entre o divino e o humano.

${ }^{2}$ Segundo a interpretação de SOARES (2007), Abel primeiramente conhece Anneliese Ross, e, após retornar ao Recife, é que passa a conviver com Cecília.

3 "Poderei, entretanto, descrever as cidades que flutuam no corpo como refletidas em mil pequenos olhos transparentes? Como dizer que penetro nesses olhos - olhos ou dimensões - e constato que as cidades, ai, são ao mesmo tempo reflexos de cidades reais e também cidades reais? Inumeráveis, íntegras, eis as cidades de Roos, erigidas nos ombros, nos joelhos, no rosto" (LINS, 1974, p. 33).

4 "Não julgar que a existência humana, enquanto inconclusa, seja um poliedro incompleto do qual a morte é o último lado, não, o poliedro move-se e suas faces e arestas proliferam, crescem conosco, mais ou menos brilhantes, assim é com todos e mais ainda comigo, de vida dúplice, duas vezes nascida, com duas infâncias, duas idades, dois corpos, de modo que as faces do poliedro se trespassam, umas em outras se refletem: sou ensamblada, incrustada em mim [...]. Serás capaz de ver as letras, as palavras que, em certas horas, vejo ainda rastejarem sob minha pele e que, decerto, nunca silenciam?” (LINS, 1974, p. 22/34).
} 
representasse "a mobilidade do mundo e a imutabilidade do divino" (LINS, 1974, p. 24). Outra linha narrativa é a da descoberta feita por Abel, na Biblioteca Marciana de Veneza, da versão grega de um poema místico, cuja estrutura baseada na espiral e no quadrado mágico orienta a construção da obra. Há, por fim, a estória de Julius Heckethorn, relojoeiro alemão nascido em 1908, cuja obra-prima - um relógio que toca uma frase da Sonata em Fá Menor K 462, de Domenico Scarlatti - vai parar, após a Segunda Guerra Mundial, na casa de Olavo Hayano, marido de $\odot$ e assassino da mulher e de Abel.

Avalovara é, portanto, um texto composto de textos, como o pássaro que dá título ao romance, feito de outros pequenos pássaros em constante mutação. ${ }^{5}$ Trata-se de uma obra que, causando profundo estranhamento, rompe grades conceituais ${ }^{6}$ ao questionar a teoria da narrativa tradicional e alça vôos em direção às origens do próprio sentido do narrar, ou seja: a narrativa não mais compreendida como um mero contar estórias, e, sim, como o ato pelo qual o real vem a nascer ${ }^{7}$, o que, em outras palavras, é o próprio poético acontecendo.

Neste sentido, parece razoável inferir que a obra de Osman Lins encaminha-se para um pensamento originário que resgata a instância poética da prosa, projetando o fazer artístico numa dimensão mítica da linguagem, tal qual concebida por pensadores da linhagem de Heráclito, Parmênides, Anaximandro, e, mais recentemente, retomada na filosofia de Nietzsche e Heidegger, por exemplo. Sendo assim, a obra, ao causar espanto, conduz-nos ao aprofundamento de cada um dos seus elementos constitutivos e suscita um percurso através das questões fundamentais que, em sua dinâmica, revelam um sentido próprio da obra de arte, imbricado no mistério da criação literária.

No presente artigo interpretaremos, portanto, a articulação que o romance faz entre a figuração do homem e da criação literária com a questão do trágico.

\section{Os elementos da narrativa em Avalovara}

Reis (1999, p. 347) alude a três propriedades fundamentais que asseguram a narratividade do texto literário:

Os textos narrativos traduzem uma atitude de exteriorização, centrada num narrador que conta a história [...]. Em função dessa atitude, os textos narrativos implicam uma representação de tendência objetiva [...]. Os textos narrativos contemplam procedimentos que instauram uma dinâmica de sucessividade.

Porém, em Avalovara, tais propriedades encontram-se fortemente questionadas, pois, ao contrário de uma narrativa realista ou naturalista, o romance não traduz

\footnotetext{
${ }^{5}$ Explicando o título da obra, o autor revela que "o título corresponde ao nome de um pássaro que existe no romance. Um pássaro imaginário. Inventei esse pássaro, não o nome. Pensava guardar para mim o segredo, mas revelo-o. Há uma divindade oriental, um ser cósmico, de cujos olhos nasceram o Sol e a Lua; de sua boca, os ventos; de seus pés, a Terra. Assim por diante. É lâmpada para os cegos, água para os sedentos, pai e mãe dos infelizes. Tem muitos braços, pois não lhe falta trabalho no mundo. Seu nome é Avalokiteçvara. Não foi difícil, aproveitando o nome, chegar ao nome claro e simétrico de 'Avalovara', que muitas pessoas acham estranho [...]. É um grande pássaro feito de pequenos pássaros. Simboliza o romance e também minha concepção de romance" (LINS, 1979, p.165).

${ }^{6}$ Avalovara abala certezas ao romper "com o horizonte de expectativas de um leitor mais tradicional, mas afeito às narrativas lineares, com suas estruturas fechadas e de foco em univocidade" (CARONE apud SOARES, 2007, p. 14).

${ }^{7}$ A imagem do lavrador que mantém cuidadosamente a charrua nos sulcos da terra é a evocação tanto do Criador que faz surgir o universo, quanto do escritor "entregue à obrigação de provocar, com zelo, nos sulcos das linhas, o nascimento de um livro" (LINS, 1974, p.72).
} 
exatamente uma "atitude de exteriorização" por parte do narrador, tampouco se observa uma "representação de tendência objetiva" contemplada num suceder racional e de fatos.

Deste modo é que, embora seja possível estabelecer um começo, meio e fim dos enredos de Avalovara, sobretudo a partir da perspectiva de Abel, que configura uma espécie de elo unificador de boa parte da trama, isso não instaura uma dinâmica de sucessividade, pois não há propriamente, na tessitura de cada fragmento narrativo (plano discursivo), a concatenação de fatos numa relação de causa e efeito. Há, sim, um constante (re)nascer do real em meio à evocação simultânea de acontecimentos ficcionais, um verdadeiro brotar fenomênico de eventos congregados, numa espécie de simbiose dificilmente imaginável a partir de uma concepção lógico-racional de tempo e espaço. ${ }^{8}$

Essa estruturação do romance abre a possibilidade de reflexões sobre a noção de verossimilhança, pois, como conceber que um ocorrido na Península Itálica em 200 a.C. possa emergir ao leitor ao mesmo tempo em que algo se dá no Brasil das décadas de 60 e 70, ou na Europa de durante e depois da Segunda Guerra Mundial? ${ }^{9}$ Ou, ainda, como conceber que um acontecimento futuro - por assim dizer - possa influir no que está acontecendo ou mesmo no que já ocorreu? Ao que parece, presente, passado e futuro (re)constroem-se mutuamente nas revoluções da linha da espiral, formando um Tempo uno, mítico, constituído de varias pequenas temporalidades reveladas a partir da dinâmica circular de expansão e concentração daquele elemento geométrico. ${ }^{10}$

Da mesma forma, o espaço em Avalovara, sob o signo do quadrado palindrômico, constitui elemento impregnado de reversibilidade, de modo a não haver qualquer ruptura semântica em passagens inesperadas, sutis ou não, por vezes num mesmo parágrafo, de um lugar ao outro: o Espaço assemelha-se ao quadrado maior que unifica os quadrados menores, portadores das letras que compõem o palíndromo, o qual pode ser lido de trás para frente, de frente para trás, da esquerda para direita, da direita para esquerda, de cima para baixo ou de baixo para cima.

Assim, tempo e espaço convertem-se em grandes questões que se co-respondem paulatinamente ao longo da obra. ${ }^{11}$

Avalovara procede, assim, a uma nítida "desnaturalização" da narrativa (PAGGANINI, 2009), pela qual as categorias fundamentais deste tipo de texto são rearticuladas criativamente. Não é à toa, portanto, que a critica costuma relacionar Osman Lins aos representantes do chamado nouveau roman (NITRINI, 1987). ${ }^{12}$

\footnotetext{
8 "É pela imitação do movimento da passagem da espiral que está organizada a trama, intercalando-se as narrativas e reforçando, no movimento de leitura linear, a sensação de simultaneidade das ações, que conta ainda com a enunciação, dentro de cada narrativa, pautada quase que exclusivamente no uso dos verbos no presente do indicativo" (SOARES, 2007, p. 21).

${ }_{9}^{9}$ Verossimilhança habitualmente compreendida como "lógica interna do enredo, que o torna verdadeiro para o leitor; é, pois, a essência do texto de ficção" (GANCHO, 2004, p.10).

10 "Não representa a espiral [...] um simultâneo ir e vir, não transita simultaneamente do Amanhã para o Ontem e do Ontem para o Amanhã? Não concilia, em seu desenho, o Sempre o Nunca?” (LINS, 1974, p. 55).

${ }^{11}$ Tomando a espiral como "símbolo da experiência mítica em relação aos ciclos temporais" e o quadrado como evocação das "limitações espaciais", SOARES (2007, p. 21-22), acredita estar "em jogo metalinguístico as duas categorias narrativas 'tempo' e 'espaço' o que no limite traduz a própria especulação sobre o narrar, em seu processo mesmo de realização".

${ }^{12}$ A ensaísta, entretanto, relativiza as semelhanças entre o autor brasileiro e os escritores do movimento francês, apontando uma distinção no embasamento filosófico das duas poéticas: “A perspectiva platônica idealista de Osman Lins adéqua-se ao seu projeto literário de colocar, na ordem do dia, a nostalgia da unidade perdida e o desejo de reencontrá-la; ao passo que o enfoque fenomenológico dos novos romancistas serve, com muita eficácia poética, ao seu objetivo de retratar a realidade em termos de subjetividade, já que para eles a natureza humana e do mundo é dinâmica e imutável" (NITRINI, 1987, p. 268-269).
} 
Não só no tempo e no espaço é possível verificar essa desnaturalização, mas também no narrador de Avalovara. Assim, a despeito da estrutura aparentemente fragmentária e das oscilações do foco narrativo, ressoa uma voz que dificilmente pode ser atribuída a qualquer dos personagens ou encaixada em uma tipologia abstrata de narrador.

Mesmo em classificações bastante abrangentes como a feita por FRIEDMAN (1967) ("autor" onisciente intruso, narrador onisciente neutro, "eu" como testemunha, narrador protagonista, onisciência seletiva múltipla, onisciência seletiva, modo dramático e câmera), a voz que em Avalovara faz cada coisa simultaneamente nascer não se encaixa.

Uma voz que conserva um mesmo estilo e ritmo e, ao mesmo tempo, está grávida da fala de cada um dos personagens, de notícias de jornais, sons diversos e, sobretudo, de silêncio. Essa voz, que parece narrar desde tempos imemoriais, contribui para uma unidade da obra em meio à diversidade de textos que a compõe, afastando o caráter fragmentário apontado por alguns estudos sobre a poética de Osman Lins. Esta voz reage, portanto, à fragmentação que permeia o modo como o homem percebe o real, principalmente a partir da modernidade.

Seria esta voz o canto polifônico do Avalovara sobrevoando em círculos as linhas do romance? ${ }^{13}$

Esta voz que privilegia o imagético e o mostrar-se fenomênico do real é que permite caracterizar Avalovara como verdadeira cosmogonia que reafirma a ação reunificante e criadora que vige na palavra. ${ }^{14}$ Uma voz que faz nascer - portanto, que narra - também se mostra como questão: quem narra? ${ }^{15}$ Quem age?

Também os personagens, tão diversos - um escravo, uma hermafrodita, uma alemã, uma mulher sem nome, um relojoeiro, um militar torturador, um escritor etc. -, em desempenhos tão singulares, não têm qualquer pretensão à verossimilhança, quer dizer, não querem mimetizar tipos sociais (pré)determinados ou estados psicológicos gerais e abstratos, mas representam o homem como questão ímpar a ser percorrida por ele próprio. Por isso, é possível inferir que todos os personagens transitam pelo mesmo e infinito percurso espiralar de autoconhecimento amoroso até os limites do quadrado equilátero tão reversível quanto o palíndromo que ele contém. ${ }^{16}$ Cada qual, sendo a figuração da própria espiral e do próprio quadrado, vai literalmente nascendo em comunhão com os demais, no "texto que os desvenda e cria" (LINS, 1974, p.13).

Dá-se, então, um co-nascimento, e isso nos conduzirá a uma identidade entre as diversas personae: elas se reconhecem mutuamente, uma vez que cada uma é constituída das demais. Por este motivo, o protagonismo de Abel experimenta algo incomum, pois ele não é o centro de convergência dos diversos enredos, vez que há narrativas em que ele sequer figura. Por outro lado, personagens como Loreius, que descobre o palíndromo

\footnotetext{
${ }^{13}$ De fato, há uma grande recorrência da imagem de pássaros de diversas cores e tamanhos ao longo de todas as narrativas componentes da obra.

14 “A voz que me fala, que me enlaça, que exalta a minha pele, o esplendor da minha carne, tudo nasce aí, nessas sementes, sim, não apenas o desejo, a força que elabora as palavras e as destila, mas também o timbre dessa voz, sua sonoridade, a voz, essa voz de bordões" (LINS, 1974, p. 88). Por ser essa uma passagem altamente erótica, evocadora da musicalidade manifesta na própria criação, impossível não relacioná-la com o dionisíaco nietzschiano em A Origem da Tragédia.

${ }^{15}$ LEITE (1989, p. 89) entende o foco narrativo como sendo "um problema técnico da ficção que supõe questionar 'quem narra?' 'como?' 'de que ângulo?'”.

${ }^{16}$ Osman Lins afirma que a obra é "um romance de amor, uma das poucas tentativas brasileiras de romance de amor" (LINS, 1979, p.165). Na apresentação feita por Antonio Candido da 2a edição de Avalovara, o crítico observa que "na narrativa, o amor é visto do homem para a mulher, da mulher para o homem, do presente para o passado, do passado para o presente, daqui para ali, dali para aqui, numa reversibilidade vertiginosa que traz à baila a evocação da herma de Jano e chega a uma mulher que é também homem, para um homem que poderia eventualmente ser também mulher".
} 
ordenador da obra, bem como $\odot$, que parece traduzir não só o afã da criação literária como o próprio mistério indizível da vida e do encontro, não podem ser legados a um segundo plano, como coadjuvantes, pois também neles se dá a agonia de todo romance.

É que a linguagem em Avalovara impulsiona a um aprofundamento sobre cada elemento da narrativa. Ao aprofundar-nos, somos levados a questioná-los; questionandoos, dá-se o desmonte do arcabouço conceitual construído ao longo de séculos de pensamento representativo, pois que já estamos no limiar do desconhecido, a partir do qual as coisas se deixam conhecer e nos indagam. Estamos na origem dos conceitos das coisas, onde vigora a dinâmica que sempre as animou.

Assim é que a construção dos personagens na obra de Osman Lins (1974), ao remeter a esta instância, manifesta a questão do que é o homem, pois, afinal de contas, o modo pelo qual se figura um personagem numa obra literária é a própria maneira pela qual ela entende o humano. Se o personagem é uma resposta possível para a questão o que é $o$ homem?, então é possível afirmar que, em Avalovara, escapando do engessamento conceitual, cada um (dos personagens), à sua maneira, em seu desempenho único, será a própria (re)elaboração da mesma questão: o que é o homem?

Por isso, é possível dizer que a obra co-responde à própria questão, convidando-nos a também co-responder à questão que nós próprios somos. Neste passo, já teremos entrado no âmbito do trágico, cujo maior paradigma, não à toa, é Édipo, ou seja, aquele que sabendo responder à terrível esfinge o que, abstratamente, seria o homem, não soube ver que homem que ele próprio era.

Passemos, pois, a uma brevíssima incursão sobre o trágico entendido como questão.

\section{A realização trágica}

A despeito de a tragediografia ática dos séculos $\mathrm{V}$ e VI a.C. ter nos revelado todo um acervo de composições em que, certamente, está presente o trágico, não parece ser possível a ela atribuir a origem da reflexão trágica.

A Ilíada e a Odisséia, as sagas dos islandeses, bem como lendas heróicas de todos os povos, do Ocidente à China, gestadas na tradição oral, já continham em si a expressão do saber trágico. Nestas manifestações aparece sempre a figura de heróis que, apesar da glória de armas e feitos, terão de inexoravelmente enfrentar a morte, um mundo de sombras, o nada. Nesta ambiência, o trágico seria a reflexão sobre a finitude das coisas e o devir da existência, figurados em fluxo dramático margeado pela Vida e pela Morte.

Daí é que o trágico não se confina às tragédias ou a um gênero teatral, mas se espraia para o épico e para o lírico, inclusive ultrapassando qualquer domínio de gênero. $\mathrm{O}$ trágico atinge todas as formas artísticas. Ele consigna aquele saber mais antigo, mais original, anterior a explicações ou sistematizações. Neste sentido, Szondi (2004) avalia que se Aristóteles formulou uma poética da tragédia (análise formal e classificatória de seus elementos), é apenas no romantismo alemão, a partir de Schelling, que surge uma filosofia do trágico, entendida como o estudo acerca de uma visão específica de mundo, ou sabedoria milenar, capaz de "apresentar a situação do homem no mundo, a essência da condição humana, a dimensão fundamental da existência” (MACHADO, 2006, p. 64).

Por isso mesmo é que o trágico também não se esgota em sua acepção comum, a de evento funesto. Nosso tempo assim o entende porque está preso ao subjetivismo - a redução do real às determinações do homem -, não percebendo que trágico é o próprio real acontecendo, lançado em seu jogo de Vida e Morte, por ação do Tempo.

Retoma-se aqui o pensamento de Heráclito no que diz respeito à noção do real. $\mathrm{O}$ real, ou phýsis, se dá em um dinamismo de ser e não ser. Ele é um sendo, de acordo com o 
estreitamento ou afrouxamento dos laços de amizade entre os opostos. Assim é que o real enquanto fenômeno é algo que se mostra e, nesse mesmo mostrar, encobre o que ele é. Por isso dizemos que o real está sempre se des-velando.

Neste âmbito é que tem lugar o pensamento filosófico originário cunhado ao longo dos tempos, referente à chamada diferença ontológica. Ora, se o real se manifesta velando o seu Ser, então, o Ser não é o que vemos. Vemos o ente (manifestação do Ser) e o ente não é o Ser. O ente se des-vela a partir do Ser, mas o Ser se vela em toda entificação. Eis, aí, uma diferença irredutível, mas também uma referência necessária entre os dois princípios, pois, se o ente somente é a partir do Ser, o Ser só é apreensível quando de sua realização no ente. ${ }^{17}$

Trágica é, então, a dinâmica de velamento do real. Tal dinâmica, que constitui o jogo a que nos referimos entre Vida e Morte (Ser e não-Ser, Destino e Liberdade etc.), dando-se em todas as coisas - portanto, em todos os entes -, é a fonte de toda criatividade. Ela se dirige ao homem, em seus percursos de realização, como o acontecer da linguagem $(\log o s)$, ou seja, o velamento das coisas que demanda a realização de sentido. ${ }^{18}$

No velamento, ou seja, no silêncio que há na fala de cada coisa é que se abre a possibilidade de criar mundos. Criar mundos é um exercício poético. É que o mostrar-se implica um esconder-se, e todo o empenho do homem é um transitar entre esses extremos, numa travessia de decifrar o indecifrável.

\begin{abstract}
Aí estão, homens e mulheres, inventados para ajudar o autor a desvendar uma ilha do mundo - e tudo, personagens e fatos, vem de um começo inalcançável. Nos seus gestos, triviais ou mesmo obscenos, eles buscam decifrar um enigma. Têm de fazê-lo. Vibra dentro deles uma presença que não se pode negar ou esquecer (LINS, 1974, p.73).
\end{abstract}

O homem não é qualquer coisa, não se resume a um ente, pois ele está sempre entre as coisas, jogado entre a liberdade e o que lhe foi destinado - sua origem inalcançável -, entre o preciso e o impreciso, entre o passado e o porvir, entre a Vida e a Morte, o Ser e o não-Ser. O homem está sempre procurando o seu sentido, e a consciência de tal sina é herança deixada por Édipo, que é retomada pelos personagens de Avalovara, como nos revela Abel:

\footnotetext{
${ }^{17}$ Como se disse, tanto a épica quanto a tragediografia já traziam em si essa reflexão, somente $a$ posteriori sistematizada pelo pensamento filosófico.

18 “Logos não é, originariamente, o fundamento metafísico divino medieval, nem uma palavra etérea, nem se reduz à lógica. Estes são distintos desvelamentos do $\log o s$, mas não o exaurem como questão e doação. A lógica é um desvelamento do logos, só que bem mais restrito do que ele" (FERRAZ, 2009, p. 43). Heidegger, após relacionar o termo legein com expressões derivadas na língua alemã - lesen (ler); holz lesen (juntar lenha); die Auslese (seleção); Ahren lesen (colher espigas) - sustenta que "o termo logos mesmo muito tempo depois de significar discurso e enunciação, ainda conservou sua significação originária, indicando 'a relação de uma coisa com outra"", a reunião de coisas, portanto. Em seguida, demonstra como em Heráclito o termo extrapola o sentido de "palavra" e "discurso". Segundo Heidegger, no citado pensador grego, a palavra significa "a unidade de reunião, i.é, o que, estando reunido, reúne (die gesammenlnde Gesammeltheit), o reunificante originário (das ursprünglich Sammelnde)." E continua Heidegger: "Logos, portanto, não significa nem sentido, nem palavra, nem doutrina, nem mesmo 'sentido de uma doutrina', mas significa a unidade de reunião constante e, em si mesma, imperante, que é a que reúne em sentido originário" (HEIDEGGER, 1999, p. 149-158). Logos é, assim, a própria linguagem (a palavra linguagem vem do mesmo radical indo-europeu leg-, que dará origem a logos). E a linguagem, antes de ser um instrumento de comunicação, é o espaço em que se "a-colhe" e "re-colhe" a diversidade concreta e deveniente do real em uma identidade.
} 
Minha vida inteira concentra-se em torno de um ato: buscar, sabendo ou não o quê $[. .$.

Empenhado na decifração e também no ciframento das coisas (embora, quase sempre, sem êxito), recuso deter-me no que é visto e captado sem esforço. Investigo aqueles planos ou camadas do real que só em raros instantes manifestam-se (LINS, 1974, p.64-73).

Em verdade, é essa busca a questão que se mostra a todos os homens e que todos tentam responder desde sempre ${ }^{19}$. Criar é o modo pelo qual o homem, em seus limites (seu quadrado?), procura responder a questão que se desenvolve em círculos (em espiral?) desde tempos imemoriais. Dito de outro modo, cada obra de arte, assim como cada existência - a suprema obra de arte -, é a elaboração única e original da mesma questão.

Sigamos, assim, ao entrelaçamento das questões: o trágico, o homem e a obra de arte.

\section{A tessitura do homem e a obra de arte}

Já partir da estruturação da obra é possível vislumbrar o desvelamento que ela faz em torno da questão do trágico. Um romance que se desenvolve entre o princípio infinito da espiral e a noção limitadora do quadrado só por isso já evoca a condição trágica, quer como diferença ontológica, quer como experiência de travessia dentro do mistério.

É a partir dos fios narrativos "S - A Espiral e o Quadrado" e "P - O Relógio de Julius Heckethorn" que se clarificam as reflexões sobre a feitura da obra e revela-se o trágico como o entre-lugar a partir do qual o homem é convocado a realizar.

A espiral não tem começo nem fim. [...] Idealmente, ela começa no Sempre e o Nunca é o seu termo [...]. Sendo a espiral infinita, e limitadas as criações humanas, o romance inspirado nessa figura geométrica aberta há que socorrer-se de outra, fechada - e evocadora, se possível, das janelas, das salas e das folhas de papel, espaços com limites precisos, nos quais transita o mundo exterior ou dos quais o espreitamos. A escolha recai sobre o quadrado: ele será o recinto, o âmbito do romance, de que a espiral é a força motriz (LINS, 1974, p. 16-19).

A reflexão sobre a liminaridade trágica do homem, que se abre, no entanto, do recinto do quadrado para o jamais limitado movimento espiralar, se conjuga com o devir de todas as coisas, submetidas ao constante florescer e fenecer:

Os relógios - escreve J.H. - têm estreita relação com o mundo e o que
representam ultrapassa largamente sua utilidade. Desde a origem, opõem ao
eterno o transitório e tentam ser espelho das estrelas. Mais ainda: exprimem em
números simples - tão simples que, ingenuamente, julgamos compreendê-los - o
ritmo impresso desde a origem à marcha solene e delicada dos astros. Vede os
relógios de Sol. Pode-se, após alguma reflexão, continuar a crer que
Anaximandro de Mileto, quando fabrica quadrantes, quer apenas facilitar a
divisão do dia em horas? O que ele pretende é converter a luz solar, seu giro
harmonioso, numa flor geométrica que feneça ao anoitecer (LINS, 1974, p.165-
166).

Ora, opor ao eterno o transitório, tentar ser espelho das estrelas -, o que seria isso senão um embate entre a Vida e a Morte? A vontade de Anaximandro em converter a luz

\footnotetext{
${ }^{19}$ Aristóteles afirmou na Metafísica (Z1, 1028 b 2 ff) que a questão que se doou ao pensamento desde sempre - a questão que todos os pensadores procuram, e para qual jamais se encontrou resposta - é "tí to ón?" ou seja, "o que é o Ser?".
} 
solar numa flor geométrica não é semelhante à vontade inexplicável do homem de criar figuras, ficções - não como o oposto ao real, mas como fingere, plasmação do real -, ou seja, fazer arte?

Ao longo dos outros fios narrativos que constituem o texto de Avalovara inúmeras são as passagens que aproximam a criação artística ao saber trágico, ou seja, a eterna luta do homem em criar o que não é nem se resume jamais a um ente, dizer o indizível, figurar o Ser como a única possibilidade de vir a ser, mas sem jamais deixar que o Ser se entifique?

Deste modo é que os percursos de realizações criativas se entrelaçam unindo a feitura da obra literária à construção daquilo que se é. E então, a tessitura da personagem na obra de arte parece corresponder à tessitura do ser humano, pois ambos vão des-velando o seu sentido ao longo do texto, na escritura do livro da vida, entre acertos e enganos, no entre-lugar que é o diálogo cuidadosamente tramado entre as diversas narrativas que os constitui.

Se "acertos e enganos [...] tecem nossa vida - e elaboram as narrativas" (LINS, 1974, p. 39), encontramos aí novamente uma referência necessária: vida e narrativa têm a mesma proveniência. São textos elaborados ao longo do Tempo entre acertos e enganos. Portanto, a reflexão em torno dos personagens é a mesma realizada em torno do fazer literário, pois, como se disse, o personagem é a figuração do homem, e o homem, ele próprio, é a questão a ser percorrida. ${ }^{20}$

No mesmo sentido, Avalovara vai nascendo a partir de várias narrativas, tal qual o próprio homem/personagem que vai nascendo dos vários homens que ele é, foi, ou pode vir a ser. Assim é que,

\begin{abstract}
Na substância da sua carne mortal, conduz Cecília o íntegro e absoluto ser de cada figura que atravessa a Praça, e não só dos homens e mulheres que agora povoam a Praça e os arredores, mas também dos que ontem a povoaram, do que em maio ou junho a povoaram, dos que no ano findo a povoaram, dos que hão de povoar ainda amanhã, destes e dos que em outras partes existem ou existiram, sim, nenhum está ausente em definitivo do corpo de Cecília (LINS, 1974, p. 158).
\end{abstract}

Da mesma forma, Abel, nascendo nas mulheres que amou/ama; Roos, em cujo corpo se edificam inumeráveis cidades; e $\odot$, nascida e nascida nas palavras que a constituem, nos remetem à mesma noção da vida como um texto misterioso e antiquíssimo revelado paulatinamente, de autoria incerta, ou indizível como a língua em que foi originalmente escrito.

Quem fez meu corpo? Observo meus pais, demoradamente, compara-os entre si, comparo-os comigo e vejo: não foram eles. Tão de longe vem meu corpo que eles esqueceram o que significa. Transmitem-no como um texto de dez mil anos, reescrito inumeráveis vezes, reescrito, apagado, perdido, evocado, novamente escrito e reescrito, numa oração clara, antes familiar, tornada enigmática à medida que transita, em silêncio, de um ventre para o outro, enquanto a língua original se desvanece (LINS, 1974, p. 28).

É que "os textos, de certo modo, existem antes que sejam escritos. Vivemos imersos em textos virtuais" (LINS, 1974, p. 64), e nós mesmos somos textos virtuais a serem feitos. Abel tem certeza de que buscar essa escritura é todo o sentido de uma

\footnotetext{
20 "O que é o homem?" co-responde à questão “o que é o Ser?", pois o homem é a partir do Ser, ou seja, aquela dimensão que, nele próprio, sempre se vela, convertendo-o, assim, em permanente questão.
} 
existência: "Caço, hoje, um texto e estou convencido de que todo o segredo da minha passagem no mundo liga-se a isto" (LINS, 1974, p. 64).

Osman Lins parece comungar dessa certeza. Tanto que fez de sua vida essa busca, essa tentativa de elaborar um rosto invisível e, em seu esforço de compreensão sobre nossa própria existência no mundo, permite que reconheçamos na criação literária a nossa prórpia criação (a criação do que somos), em desdobramentos narrativos simultâneos, rigorosos, calculados e, nem por isso, menos surpreendentes. Aliás, em Avalovara o rigor e a precisão parecem surgir como um imperativo existencial da liberdade a que estamos destinados como seres humanos. Isto é: a liberdade nasce da obediência do Destino, o que não tem nada de servil nem de submissão. E isto porque obedecer não é se submeter, mas, como a própria etimologia diz, colocar-se em posição ( $o b-$-) de escuta (audire) da questão de quem nós próprios somos, compreendendo-nos como uma obra de arte a ser permanentemente tecida entre o Destino e a Liberdade, na travessia entre o recinto limitado de um quadrado e o jamais limitado movimento de uma espiral, que não tem começo nem fim.

\section{Considerações finais}

Como se viu, o trágico surge não só na estruturação de Avalovara, mas também no desempenho de cada personagem ao longo da obra, vez que estão todos lançados numa travessia de autoprocura que os convida a uma constante (re)elaboração criativa da existência como própria possibilidade de realização do humano.

Por isso, é possível dizer que, na leitura de Avalovara, "chegamos, através do mundo (erradio, os nossos passos?), a este ponto de intersecção" em que se dá a fusão de horizontes entre o homem e a obra de arte, criação e criação, ambos para além de seus limites. Como no romance se diz, "aqui não há desordem. Estamos numa esfera de milagres, onde os fragmentos se ajustam e se refaz o uno" (LINS, 1974, p. 42).

Este lugar é a evocação do próprio logos, tal qual no fragmento 50 de Heráclito (1991, p. 71): “Auscultando não a mim, mas o logos, é sábio concordar que tudo é um”. É possível, então, perceber que é a partir do logos - desse ponto de intercção, desse limiar de sentido - que se abre a possibilidade de nos escrevermos no mundo.

Assim,

\footnotetext{
Este frágil equilíbrio: lápis com a ponta sobre uma base plana, o eixo de gravidade, mais delgado que um fio de cabelo, descendo ao longo da grafite e incidindo sobre a exígua base. Vai inclinar-se e tombar. Sabemos, e nunca mais, sabemos, nunca mais. Coordena-se um texto, geométrico, dentre inumeráveis letras desconexas (LINS, 1974, p. 43).
}

Na construção desse texto, colocamo-nos novamente em marcha criativa, sempre à procura de sentido para as questões que nos permeiam e que ontologicamente somos.

Portanto, fica estabelecida uma referência entre o Homem e a Obra Literária, de modo a dizer que ambos são ficcionais: o sentido de ambos é construído na Linguagem (logos), em um diálogo conduzido cuidadosamente através da rigidez do quadrado e da fluidez do movimento espiral, entre as diversas narrativas que se entrecruzam para constituir o tecido da existência. 
Por esses e por outros motivos, há que se reconhecer a grandeza monumental desse romance estruturado sob a égide de um esquema rigoroso. ${ }^{21}$ Romance que se assenta na idéia de uma ordem do mundo, tal qual se diz das catedrais góticas medievais, capazes de reunir em sua constituição diversos saberes e artes, tais como a geometria, a música, a mitologia, a filosofia, a religião, as artes plásticas etc.

Diante disso, é forçoso concluir que seria impossível edificar uma interpretação completa que dê conta dos universos entreabertos por Avalovara. Essa impossibilidade, entretanto, é antes uma dádiva, pois constitui o empuxo necessário e propiciador de infindos percursos hermenêuticos. Com isso, admite-se que este é apenas o início de um destes percursos, e que há muito ainda a ser trilhado.

\section{REFERÊNCIAS}

ANAXIMANDRO; PARMÊNIDES; HERÁCLITO. Os pensadores originários. Tradução de Emmanuel Carneiro Leão e Sérgio Wrublewski. Petrópolis: Vozes, 1991.

ARISTÓTELES. Metafísica. Tradução, prefácio, introdução, comentário e apêndices de Eudoro de Sousa. Lisboa: Casa da Moeda, 1998.

DALCASTAGNÈ, Regina. A garganta das coisas: movimentos de Avalovara, de Osman Lins. Brasília: Editora Universidade de Brasília: São Paulo: Imprensa Oficial do Estado, 2000.

FRIEDMAN, Norman. Point of view in fiction, the development of a critical concept. In: STEVICK, Philip, ed. The Theory of the Novel. New York: The Free Press, 1967

GANCHO, Cândida Vilares. Como analisar narrativas. São Paulo: Ática, 2004.

HEIDEGGER, Martin. Introdução à metafísica. Apresentação e tradução Emmanuel Carneiro Leão. 4. ed. Rio de Janeiro: Tempo Brasileiro, 1999.

LEITE, Lígia Chiappini de Moraes. O foco narrativo. São Paulo: Ática, 1989.

LESKY, Albin. A tragédia grega. São Paulo: Perspectiva, 1996

LINS, Osman. Avalovara. 2. ed. São Paulo: Melhoramentos, 1974.

MACHADO, Roberto. O nascimento do trágico: de Schiller a Nietzsche. Rio de Janeiro: Jorge Zahar Editor, 2006.

NIETZSCHE, Friedrich. A Origem da tragédia. Tradução Joaquim José de Faria. São Paulo: Centauro Ed., 2004.

NITRINI, Sandra. Poéticas em confronto: Nove, Novena e o novo romance. São Paulo: Hucitec; Brasília: INL; Fundação Nacional Pró-Memória, 1987.

PEREIRA, Marcio Roberto. Osman Lins: ruptura e inovação em Avalovara. In: CONGRESSO INTERNACIONAL DA ABRALIC, 11., Anais, 2009.

REIS, Carlos. O conhecimento da literatura: introdução aos estudos literários. 2. ed. Coimbra: Livraria Almedina, 1999.

\footnotetext{
21 "Rege nosso romance uma mecânica que se pretende tão rígida quanto a que move os astros" (LINS, 1974, p. 71).
} 
SOARES, Marisa Balthazar. Tempo de Avalovara: diferentes dimensões temporais no romance de Osman Lins. 2007. 168 f. Tese (Doutorado) - Faculdade de Filosofia, Letras e Ciências Humanas, Universidade de São Paulo, São Paulo, 2007.

SZONDI, Peter. Ensaio sobre o trágico. Tradução de Pedro Süssekind. Rio de Janeiro: Jorge Zahar Editor, 2004.

Recebido em: 16 de janeiro de 2012.

Aprovado em: 01 de setembro de 2012. 